\title{
THE SLUG PROBLEM
}

\author{
B. P. Coleman
}

Department of Agriculture, Auckland

\section{Summary}

Little is known of the species of slugs present in New Zealand. Rather less is known of their life-cycles and of their ability to adapt from forest to pasture and from pasture to vegetable cropping. Brief details are given of the main pest species and a summary of the damage they cause to susceptible vegetable crops. The use of metaldehyde for control of slugs is noted and the need for field trials with other chemicals, such as methiocarb, pointed out.

INFORMATION on slugs in New Zealand is far from complete. Little is known of the distribution of species and their economic importance has not been truly assessed.

The most important work on introduced species, which appear to be the main pests, was published by Musson in 1890, the New Zealand records being revised by Suter in 1891, 1895 and 19.32. Thomson (1922), Quick (1952) and Whitten (1955) all provided valuable information.

Unfortunately, the preservation and maintenance of slug specimens is difficult and they do not occupy an important place on our faunal lists.

Slugs are a natural, although rather temporary, part of the organic complex of the soil and use the soil for shelter and to provide some food and scavenging territory. Unfortunately, estimation of species is difficult - especially of those committed to a subterranean existence. Some work on this problem is needed before any new material can be evaluated.

Species were probably introduced with horticultural stock, becoming established first at the port of entry and then, in association with man, building up in urban areas and spreading to natural surroundings. Horticultural stock and possibly birds are probably the main means of distribution. The Maori, who grew large areas of kumeras prior to European settlement, has no record of slugs as a pest (Best, 1925) in a crop which today is regarded as the most susceptible of the root crops.

Damage can be considerable, both directly and by secondary fungi and/ or bacteria. It has been assessed in Europe that a slug can devour $350 \mathrm{~g}$ of plant tissue but that rotting of the gnawed produce causes losses twenty to thirty times greater.

The use of organic fertilizers in vegetable cropping contributes to the build-up of slug populations. Encouragement of green cropping programmes furthers it. With vegetable exports being encouraged, and in fact growing, slug infestation oan present a significant problem. 


\section{SLUG SPECIES}

The following include the main pests among the introduced species of this country:

\section{Family ARIONIDAE}

The slugs of this family have no real shell although some remnants or grains of shelly material may be found beneath the mantle at the rear.

Arion ater (L.). Auckland to Dunedin.

Grows to $120 \mathrm{~mm}$ in length; colour variable; black not keeled and covered in coarse tubercles. Omnivorous, eats decayed vegetable matter, potato and root crops but does not eat green vegetables. Has been known overseas to feed on dead mice and rabbits and animal faeces. Inhabits grass fields.

Arion subfuscus Drap. Dunedin.

Smaller and rounder than $A$. ater. Colour light reddish-brown, faint black bands on sides. Slightly keeled at rear.

Arion hortensis Fér. Plentiful in Auckland district; also found in Taranaki.

Small, usually less than $40 \mathrm{~mm}$. Often confused with young specimens of $A$. ater as both species have no keel. Can be distinguished by its relative slenderness and the back being longitudinally striped. It is a pest overseas and burrows deeper into soil than other species - probably escapes some mechanical damage from plough or rotary hoes. May live deep in soil on ploughed-under turf for 6 weeks and emerge to damage crops. Eats potatoes, carrots, kumaras. Overseas, dominant species on potatoes. Clay soils in autumn. Not as susceptible to metaldehyde as A. ater. Tends to increase in undisturbed land.

Arion minimus (Sim.). Rangitoto and Masterton.

Rather a tentative identification. Similar to A. hortensis but specimens over $12 \mathrm{~mm}$ not found. October and autumn best time to attack.

\section{Family MILACIDAE}

This family and the closely related Limacidae have thin shells beneath their mantles. This family can also be distinguished from the Arionidae from the positioning of the sinus in the mantle. In Milacidae the sinus is to the rear and in Arionidae towards the front.

Milax gagates (Drap.). Auckland, Hawke's Bay, Thames.

Variable in colour; 40 to $60 \mathrm{~mm}$ in length. Suter named 3 species in New Zealand. Whilst not uncommon in Auckland, is rarely encountered. Distinguished by a prominent keel running from mantle to the tail. The shell is small, oval and iridescent. Found overseas on potatoes.

\section{Family LIMACIDAE}

Agriolimax laevis Mull. Common throughout New Zealand.

Up to $50 \mathrm{~mm}$ in length, it is glossy dark brown with a paler mantle, and quite active. The shell is fingernail shaped and if touched when 
crawling tends to arch its back similar to a looper caterpillar. Usually inhabits damp places such as swamps, borders of woods. Has been noted overseas as devouring mealy bugs. Not a bad pest generally.

Agriolimax reticulatus Mull. (syn. A. arestes). Widespread.

Colour varies but usually ash grey with some brown. When resting, distinct tubercles can be seen. The back is keeled towards the tail and the shell concave below, flat above, thin and oval. Common in New Zealand in grass fields, hedges, woods, gardens, under stones and logs. Overseas common on potatoes. Active in clay soils in autumn. Rather more susceptible to metaldehyde than $A$. ater. Summer control best.

Limax maximus (Linn.). Auckland, especially Papakura, Manurewa; Taranaki, Manawatu, Dunedin.

The largest slug found in New Zealand, growing to $150 \mathrm{~mm}$. Varied colouring, skin wrinkled, slight keel towards the tail. The shell convex above, flat to concave below and oblong. Has an undeserved reputation as a predator of smaller slugs. Non-chloryphyllous.

Limax flavus (Linn.). Common.

The tiger slug. Green to yellowish slug, foot edged with yellow. The mantle is yellow with black and white spots giving a somewhat checkered effect. Shell oblong, concave below. Will feed on carrots. Has been known to feed on fungi.

\section{SLUG DAMAGE IN NEW ZEALAND}

Susceptible vegetable crops are as follows:

Brassicas - Brussel sprouts, cabbage, cauliflower: Damage to seedlings - field plants, leaf damage, physical presence and faecal fouling on mature heads.

Carrots and Parsnips: Foliage feeding, root damage and secondary disease, both fungal and bacterial.

Celery: Chewing of stems, secondary bacterial soft rot, physical presence and faecal fouling.

Kumara: Damage to plants in propagating beds, plants set out in the field, and tubers. Damaged tubers invariably infected with fungus and collapse during curing and/or storage.

Lettuce: Seedling bed damage often severe enough to interrupt planting programmes.

Potatoes: Tuber damage causing degrading of crop and secondary infection. Losses of up to $50 \%$ have been noted in New Zealand.

Pumpkins: Damage to immature fruit with subsequent rotting through entry of secondary infection in store.

Silver Beet: Leaf damage and secondary rots.

Tomatoes: The fruit of dwarf tomatoes grown for processing are susceptible to slug damage. 
As can be seen, damage to seed-beds and loss of seedlings may cause a breakdown in a planned cropping programme. With mechanical planters in common use, loss of plants set out in the field results in replanting by hand. This is a costly business today.

Tuber losses can be illustrated in the following manner. Kumara plants are set out at approximately 18,000 plants per acre. If slug damage occurred on 1 tuber weighing $8 \mathrm{oz}$ on $25 \%$ of the crop, this would represent a total of 1 ton degraded and unsuitable for curing and storing.

The presence of the live slug and faeces on crops is repugnant to the buyer. The question of plant quarantine regulations in regard to export must also arise.

In New Zealand, slugs appear to be active all the year round. Much has been published on their preference for high humidity and moist substrate, but overseas, Dainton (1954) has shown that temperature is the main factor in slug activity. At falling temperatures they become active below $21^{\circ} \mathrm{C}$ and at rising temperatures above $21^{\circ} \mathrm{C}$.

Some species can stand sub-freezing temperatures - others have been snap frozen at $-15^{\circ} \mathrm{C}$ (Getz, 1959).

Generally the knowledge necessary in New Zealand for a scientific approach to control is the ecology of this group of molluscs, their distribution in relation to vegetation, ranging and homing habits, and certainly breeding cycles.

All species are monoecious and many can both self- and cross-fertilize. Cross-fertilization acts in one direction only, one member acting as a male and one as a female without any clue as to which is which (Williamson, 1959). Many species act in pre-copulatory movements of a circling nature; in particular, Limax maximus indulges in spectacular acrobatics during copulation (Chichester and Getz, 1968).

As vectors of disease they are regarded with some suspicion, and have been found implicated in the spread of downy mildew of beans (Webster et al., 1964) and cabbage leaf spot (Alternaria brassicicola) (Hasan and Vago, 1966). Spores apparently pass intact through the alimentary tract. Viable conidia has been found present in the slime covering a live slug after 5 days.

Overseas potato varieties seem to vary in their susceptibility to slug attack (Gould, 1965), maturity and vigour of growth being of no significance. Where blight is present, slug damage seems more severe.

\section{CONTROL}

Early slug control was based on burnt lime, hydrated lime and dehydrated copper sulphate. In 1923, the New Zealand Journal of Agriculture recommended the use of hedgehogs where there were no frogs in the vicinity.

A breakthrough came in 1936 (Thomas, 1936) when a solid fuel used for heating curling tongs was found deadly to slugs. The main ingredient was the well-known metaldehyde, and until recently this material plus attractants was the basis of all slug controls. Originally a loose mixture, it was compressed into coarse pellets, and fungistats were added to prevent destructive moulds disintegrating the pellets. Because of unevenness of distribution, pellets were reduced in size and these micro-pellets gave a greater number of killing points. Metaldehyde has also been used in suspension for spraying of crops. Combinations of metaldehyde and most 
other insecticides have been tried, some having some merit. Carbaryl in some cases in combination has been rather effective (Ruppel, 1959).

At the Brighton Insecticide and Fungicide Conference, Hunter (1969), lately of the Slug Research Unit at Cambridge, considered the effects of increasing metaldehyde percentage and application rates, and the possibility of introducing contact killers (although this has been tried in the past).

He pointed out, as have other workers in England, the new material methiocarb which appears to attract more slugs than metaldehyde and has the important non-recovery factor. Field trials need to be carried out with this material in New Zealand, especially to determine what species it controls. Under trials at Cardiff there seemed to be some significant improvement over metaldehyde, and on small unreplicated trials in New Zealand methiocarb has shown some promise.

\section{REFERENCES}

Best, Elsdon, 1925: Dom. Mus. Bull. 9.

Chichester, L. F.; Getz, L. L., 1968: The Biologist, 50 (3-4).

Dainton, B. H., 1954: J. exp. Biol., 31: 165-87.

Getz, L. L., 1959: Amer. Midl. Nat., 61: 485-98.

Gould, H. I., 1965: Plant Path., 14 (3) : 109-11.

Hasan, S.; Vago, C., 1966: Plant Dis. Rep., 50: 764-7.

Hunter, P. J., 1969: The Grower, Dec. 13.

Musson, C. T., 1890: Proc. Linn.Soc. N.S.W., 5 (Ser. 2): 883-96.

Quick, H. E., 1952: Proc. Mal.Soc. London., 29 (5).

Ruppel, R. F., 1959: J. econ. Entom.

Suter, H., 1891: Trans. N.Z. Inst., 24: 279-91. , 1895: Trans N.Z. Inst., 28: 323.

ton. , 1913: Manual of the New Zealand Mollusca: 1071-3. Welling-

Thomas, G. W., 1936: Gardeners' Chronicle, Dec. 19: 453.

Thomson, G. M., 1922: The Naturalization of Animals and Plants in New Zealand: 258-64. Cambridge Univ. Press.

Webster, R. E., et al., 1964: Phytopathology, 54: 749.

Whitten, H. E., 1955: Bull. 11, Conchology Section, Auckland Museum: 1-7.

Williamson, M. H., 1959: Proc. Roy. Phys. Soc. Edinb., 27: 87-93. 